\title{
THE RÔLE OF THE INSURANCE COMMISSIONER IN INDUSTRIAL LIFE INSURANCE
}

\author{
- Clarence W. Hobbs*
}

Industrial life insurance is merely life insurance, sold in small policies, the average Industrial policy being somewhere between $\$ 200.00$ and $\$ 250.00$, and with a premium which is ordinarily payable in weekly instalments and collected at the door. It is adapted to the needs of those who cannot buy the ordinary forms of life insurance, but who wish to provide either for the protection of their families or for the expense of their burial. Any life company can write it. There were in 1932 some 79 companies listed as having Industrial life insurance on their books. Some of these, to be sure, had only a nominal amount; but while three companies write the greater part of the Industrial business, there are others who write it actively and in very fair amount.

The functions of the Insurance Commissioner with regard to companies writing Industrial life insurance do not differ in kind from those relating to life companies generally. It is his duty to exercise certain supervisory functions designed to secure their solvency and the proper conduct of their business with regard to the rights of their policyholders, and in compliance with law. As in the case of other companies, he licenses out-of-state companies, requires the filing of an annual statement showing in detail their financial condition and their operations, examines and audits this statement, determining their assets, the valuation of their investments, and the amount of their liabilities, including the great reserves which life companies maintain against their policies in force. He makes examinations, examines and approves policy forms, takes action if necessary to revoke a license or to require a company to put itself into sound condition, licenses agents, and in general sees that the companies comply with each and every statutory requirement. He hears complaints arising out of their method of transacting business or the adjustment of claims.

The extent to which Industrial life insurance presents a special problem to the insurance commissioner is due chiefly to the immense volume of the business and the great size of some of the companies writing it. On the latter point it may be

- A.B., I902, LL.B., I904, Harvard University. Member of Massachusetts and New York Bars. Member of Massachusetts House of Representatives, I910, I9זI, I9I2; Massachusetts Senate, I9I3-I9I9. Commissioner of Insurance of Massachusetts, 1919-1923. Special Representative of the National Convention of Insurance Commissioners in the National Council on Compensation Insurance since 1923. Author of numerous articles, pamphlets, and addresses on insurance subjects. 
said that the chief writers of Industrial life insurance are enormous companies, and the labor of auditing and checking the annual statement, of determining financial condition and of making examinations increases quantitatively with the size of the company. On the other hand, it may also be said that these same companies are very well managed institutions; that there is no real question as to their financial condition, and that they exhibit a genuine desire to keep within the law. On the former point, Industrial insurance outstanding in the United States amounts in round numbers to $\$ 17,000,000,000$, divided in $80,000,000$ policies, and new issues are in the vicinity of $15,000,000$ per annum. In other words, the Industrial companies reach each year something better than one in every ten of the inhabitants of the United States, and their outstanding insurance includes better than one-third of the population and involves visiting this enormous constituency once a week. Insurance, or for that matter, any business cannot touch so many people without developing points of friction, and a certain amount of the trouble generated thereby comes to the desk of the Insurance Commissioner. But on this point it does not differ from any type of insurance, and the number of complaints as compared with the enormous volume of transactions does not seem unduly large.

The points in which Industrial insurance presents problems which may be regarded as peculiar to the business may be briefly listed and discussed.

\section{The Valuation of Policies}

All life policies are valued for the purpose of determining what reserve the company shall maintain to ensure their ultimate payment. Industrial life policies are valued like any other policies. The old method of seriatim valuations is not now maintained by many insurance departments, and could hardly be used with regard to industrial issues. A grouped mean valuation is generally used and is for all practical purposes quite as accurate. In view of the fact that Industrial business carries a higher mortality than Ordinary life business, the statutes permit the use of special Industrial tables for valuation purposes, reflecting this higher mortality rate. One table more or less, however, does not add to the burden of insurance departments.

\section{The Approval of Policy Forms}

Industrial life policies are generally subject to approval as to form; but the ordinary "standard provisions," so called, are generally not required to be inserted. Some modification of the standard provisions was necessary because of the peculiar conditions attendant upon Industrial insurance; and while the greater part of the items included in the standard provisions, such as incontestability, grace period, misstatement of age, reinstatement and non-forfeiture values, appear in the Industrial policy, they are not always in the exact form of the standard provisions. Originally, the Industrial policy was some distance from the standard provisions. Now the 
policy has become pretty well standardized, and is very close to such of the standard provisions as are at all applicable.

A very substantial proportion of the complaints addressed to insurance departments involve the older issues of Industrial policies. Prior to 1907 these generally did not contain cash surrender values, and some of the older issues did' not contain the options of paid-up insurance or extended insurance in the event of cessation of premium payments. The old policyholders had some reason to feel aggrieved at seeing the new policyholders getting a more liberal contract; especially when they were compelled to give up premium payments and found themselves unable to get a cash surrender value. One large company, with the aid of statutory provision in its home state, extended these privileges to all old policyholders in a measure defined by the statute. Other companies adopted the policy of extending relief in meritorious cases. The problem is one which is growing less as the older issues pass off the books. The one marked difference between an Industrial life policy and an Ordinary life policy is the lack of a policy loan privilege. But the small size of the policies and the consequent small dimensions of the policyholder's equity makes this privilege practically impossible to give without a great increase in cost. Policy loans on industrial policies are not unknown, but are very rare, and granted only in exceptional cases. It may be stated that the forms of Industrial policies now in use create a minimum of complaint as to their essential equity.

\section{THE INDUSTRIAL ÀGENT}

The writing of the vast volume of Industrial business and the regular collection of weekly premiums requires the service of a perfect army of agents. These form the contacts between the companies and the great industrial population of the country. That population comprehends highly diversified racial elements and a great variety of social backgrounds. No small part of it is but imperfectly acquainted with the English language. Of necessity the agents must be such as can readily meet and talk with this constituency, and in consequence the make-up of the agency force is very nearly as heterogeneous as the population. The army is not levied haphazard, nor is it without its discipline and training. A company has too much to lose from sending out irresponsible persons to represent it to take more chances than it must. It sets up certain standards for selection, and the tendency is towards the raising of its standards. It maintains an elaborate organization to supervise, to check and to audit the transactions of these agents. It sets up and enforces rules as to their conduct, gives instruction, and where the volume of business warrants sometimes conducts regular schools. On top of this, the agents must in practically all states receive licenses. New York does not require licenses for Industrial agents, but even there at least one Industrial company has all its agents licensed, inasmuch as it permits them also to write Ordinary insurance as well as Industrial. The licensing process constitutes a certain safeguard to the public. Many states require some proof that 
the company has exercised due care in its selections; some add a regular examination to test their knowledge of the business. All states have power to revoke licenses for cause. By this means, the unfit may be readily removed.

To be sure, the process is not a perfect one. The army is under constant change as men drop out or are removed and new ones are recruited to take their place. The work of collection must go on; solicitation of new business must continue. The new recruits must receive part of their training, not in advance, but by experience. None the less, the process is so far effective that the great body of Industrial agents operates in the community with, on the whole, a less percentage of delinquencies than would be expected of a body of men of like size. It must be borne in mind that even the learned professions, the lawyers, the doctors, even the ministry, have their black sheep.

The Industrial agents are undoubtedly less highly educated, and have generally a lowlier background than the professions; but morally they probably average very well, and are under a deal closer discipline and control. Once in a while an Industrial agent may fail to account for his collections, or may make himself party to a fraud against his company. But complaints on this point play no great part in the commissioner's office.

The most fruifful source of complaints against Industrial agents come under the head of misrepresentation, arising out of their dealings with policyholders or others. The hearing of these complaints involves the taking of a deal of evidence, and the recording of conversations between an agent and a person or persons perhaps imperfectly acquainted with the English language, frequently neither clever nor educated, and generally unused to scanning the provisions of a policy. Case after case develops a conflict as to what was said, and it is no easy matter oftentimes to determine whether there was a real misrepresentation or merely a failure of the parties to understand each other. Once in a while, however, a complaint does develop a real case of misconduct. The writer while commissioner seldom heard these cases personally, but submits for illustration two cases in Industrial policies which came within his personal attention.

The first case involved a policy written upon the life of a man then in the last stages of cancer of the mouth, a condition obvious at a glance. The agent appeared to have encouraged the man to take out the insurance, representing that in his condition it was an excellent speculation. The man was thus induced to put his name to an application warranting that he was in good health. He died within a few months; and the agent, foreseeing trouble, went to the widow, picked up the policy, representing that he needed it in order to collect the principal, and, once it was in his possession, told her that there was nothing coming to her.

In this case, the company. was not liable in that particular state, in view of the patent breach of warranty. There was ground for revoking the agent's license, both for the solicitation under the circumstances, and for the method by which he got 
possession of the policy. In view of a previous good record, and the fact that he was the sole support of a crippled son, he was permitted to compound the matter by making personal payment of the face of the policy.

The second case involved a charge of misrepresentation or rather of concealment of facts, made by an undertaker. The inmate of an almshouse died, having in force two Industrial policies. The undertaker obtained from the agent information as to the amount of insurance, namely, five hundred dollars, and gave the pauper a funeral calculated to use up most of it. Unfortunately, only one of the policies was payable to the estate. The other was to a named beneficiary who declined to be answerable for any part of the bill. The undertaker claimed the agent ought to have told him the facts. The agent testified that he was not aware that the second policy was payable to a named beneficiary. This complaint was dismissed, there being no evidence of breach of any duty owed by the agent to the undertaker.

These illustrate the kind of cases which occasionally come to the commissioner's desk. The solicitation of insurance upon persons whom the agent knows not to be proper subjects for insurance is a thing to which the temptation is always strong. The agent needs the commission; it may be he wants to make a record by turning in a number of applications. He takes a chance. In any event, the premiums paid will be returned, and it may be the insured will outlive the period of contestability. Meantime, he has his commission, and his record is that much better. In some states, knowledge on his part would be considered knowledge of the company. In Massachusetts, that is not the case; but for a long time the state's law required a medical examination upon the issuance of a policy. This created a deal of trouble in Industrial cases, for naturally on small policies no very extended examination could be given. Examinations were extremely technical, and were sometimes not even that. Ultimately the state exempted from the law policies of less than $\$ 500$.

The matter of the undertaker involves a topic which will be discussed more at length hereafter.

Here it may be stated again that, considering the number of transactions, the number of complaints based upon the acts of agents is not large. An Industrial policy involves not only the solicitation and writing of the policy, but some fifty-two domiciliary visits per annum thereafter. Theoretically, all sorts of complications are possible. Actually, the volume of complaints bears a very small proportion to the number of transactions; and of the complaints made, not all by any means are wellfounded. The Industrial agent is individually not an imposing figure. He must begin very small, and his road to a competence involves patience and energy. But success comes in this field as elsewhere to him who seeks it diligently.

\section{The Setrtement of Claims}

Complaints that a company is improperly avoiding payment of a claim are very rare in case of all life companies. 
The happening of the contingency is usually provable with a minimum of difficulty; the amount payable is fixed by the terms of the policy, and it is only in cases where death cannot be proved, cases where there is a question of misstatement of age, or cases involving fraud vitiating the contract or the like that occasion arises for compromise or contract. So far as can be judged from the figures of the New York reports as to settlements in New York State, the percentages of compromises and rejections are quite as low on Industrial as on Ordinary business. The following figures, taken from companies writing both Ordinary and Industrial business, upon their transactions in New York State for the calendar year 193x, are cited to illustrate.

\begin{tabular}{|c|c|c|c|c|}
\hline $\begin{array}{l}\text { Types of } \\
\text { Insurance }\end{array}$ & $\begin{array}{l}\text { Settlements } \\
\text { In Full }\end{array}$ & $\begin{array}{c}\text { Claims } \\
\text { Compromised }\end{array}$ & $\begin{array}{l}\text { Claims } \\
\text { Rejected }\end{array}$ & Total \\
\hline $\begin{array}{l}\text { Ordinary } \\
\text { Industrial }\end{array}$ & $\begin{array}{r}\$ 46,493,420 \\
\cdot 37,971,289\end{array}$ & $\begin{array}{r}\$ 443,732 \\
178,314\end{array}$ & $\begin{array}{r}\$ 57,363 \\
60,577\end{array}$ & $\begin{array}{r}\$ 46,667,515 \\
3^{8,210,190}\end{array}$ \\
\hline
\end{tabular}

There is a good reason why there should be a low percentage of settlements refused on Industrial cases. The average size of claims is less than \$200. To resist a claim in the courts involves a cost greater than the amount of the policy. In selfprotection the company must resist claims definitely fraudulent, or cases involving an important legal principle, but such cases are rare; and it has a very natural distaste to appearing in the rôle of the big corporation holding up the little fellow. Neither juries nor the insurance departments approve of a contest not based on the soundest of evidence. Consequently, complaints that a life company, Industrial or otherwise, is misusing legal process are rare indeed.

It is sometimes argued that the small claimant is much at the mercy of the insurance company because of the cost of pressing his claim in the courts. But there seems no great difficulty about litigating small claims, and it is probable that the litigation costs the insurance company more than the assured. No insurance company, least of all a life company, enjoys litigation, and the above figures indicate that they keep out of court when they can.

\section{The "Facility of Payment" Clause}

All Industrial policies contain a clause reading substantially as follows:

"The company may make any payment or grant any non-forfeiture privilege provided herein to the insured, husband or wife, or anyi relative by blood or connection by marriage of the insured, or to any other person appearing to said company to be equitably entitled to the same by reason of having incurred expense on behalf of the insured, or for his or her burial; and the production of a receipt signed by either of said persons, or of other proof of such payment or grant of such privilege to either of them, shall be conclusive evidence that all claims under this policy have been satisfied."

This clause is inserted in order to cope with the varying situations arising on the death of an insured and to permit of a settlement without compelling the insured's 
beneficiaries or his estate to take out administration-a process which in these small amounts would often eat up the entire sum. Where the policy contains a named beneficiary, the settlement would ordinarily be made with the beneficiary. But where the beneficiary has died, where the beneficiary is a minor or non compos mentis, where the beneficiary is abroad or cannot be found, or where there is a dispute as to who is the beneficiary, then the clause permits the company to make a settlement with somebody who may be regarded as equitably entitled to the proceeds. Where the policy is payable to the estate, the rights of creditors must be given consideration, and here enters the picture of the grasping undertaker in cahoots with the wicked agent. The undertaker is, to be sure, a creditor of the estate and a preferred creditor at that; and it is natural to suspect him of being entirely willing to make his bill in accordance with the amount of insurance, and to be willing also to induce an agent or other functionary to tip him off. But the companies forbid persons in their employ to give out information of this kind, and furthermore do not make settlements with the undertaker himself, except in very unusual cases. Where there are conflicting claims, the practice is to endeavor to secure an agreement. A company very likely would feel that the reasonable expenses of burial ought in equity to be paid, but would certainly not go out of its way to help an undertaker collect a bill which went at all beyond the bounds of reason. The writer is inclined to think the possibilities in this clause are far ahead of the actualities. The companies have every reason on earth to desire to maintain a contented constituency; ordinarily, no reason whatever to favor one party at interest over another. At all events, complaints based on a misuse of this clause are very rare.

\section{The Cost of Industrial Insurance}

Every now and then the charge is levied at the Industrial companies that the cost is high. This was featured at the time of the Armstrong investigation, and has returned sporadically since. Massachusetts felt so seriously on the subject as to authorize the issuance of policies not to exceed \$rooo by savings banks, with the state appropriating money to cover a part of the expense. This was successful in producing a low-cost life insurance, but while the system did at first write some Industrial business, it does not write policies of the Industrial size to any great extent, its average policy being very close to the permissible. No doubt the cost of Industrial insurance is greater than that of Ordinary life insurance. This is due to these facts:

(a) It costs a certain minimum amount to write and place a policy on the books irrespective of its size.

(b) It costs more to transact insurance payable in weekly instalments collected at the door than it does to transact insurance at an annual premium collected direct or through an agent.

(c) The mortality rate on Industrial business is higher than the rate on Ordinary business. 
All these factors make for additional cost, and this is reflected in the rates charged. At least one company permits a person who desires to avoid the cost of the weekly collections to do so by paying his premium over the period of a year direct to the district office, thus avoiding so much of the cost as goes for the collection. A goodly number of policyholders take advantage of this privilege. But for the great majority of the business, the weekly payment and the collection at the door are important matters-and apparently worth what they cost.

To summarize the foregoing it may be said that the main problems of Industrial insurance arise, not out of questions connected with the ordinary matters of supervision, but out of selling insurance, premium collections, and adjustments; and that the main sources of problems arise from charges of misrepresentations by agents and from claims for cash surrender values and other policyholders' equities upon old contracts which do not carry these values. But after all is said and done, the amount of trouble which the business generates, though quantitatively a considerable item in the insurance commissioner's office, is not large when contrasted with the volume of transactions which go through without complaint. The Industrial business presents some very striking pictures. Here are individual companies, each with its army of agents, making contact with policyholders sufficient in number to constitute a good-sized nation. From these policyholders, scattered the length and breadth of the Union, flow weekly driblets of coin which collect into a mighty stream comparable with the revenue of a state. It flows into the company's treasury, circulates through the channels of investment and returns with increment to flow back whence it came in the form of payments to policyholders and beneficiaries. The great operation goes on daily and continuously, with ease and smoothness, marred now and then by a ripple of disagreement, but with no serious break calculated to excite the indignation of policyholders generally or to incur the resentment of supervisory officials. The companies do business in many states and, save in their home states, purely on sufferance, by virtue of an annual license revocable for cause. The long and unbroken relations which they have maintained with many and ever-changing supervisory officials are good evidence of the general disposition of the companies to comply with the law, and of the general fairness of their transactions and the equity of their contracts. 